\title{
Advances in Welding Metal Alloys, Dissimilar Metals and Additively Manufactured Parts
}

\author{
Giuseppe Casalino \\ Dipartimento di Meccanica, Management, Matematica (DMMM), Politecnico di Bari, viale Japigia, 182, \\ Bari 70126, Italy; giuseppe.casalino@poliba.it; Tel.: +39-080-596-2753; Fax: +39-080-596-2788
}

Received: 10 January 2017; Accepted: 23 January 2017; Published: 25 January 2017

Nowadays, strong, light-weight, multi-functional, high performing products are key for achieving success in the worldwide markets. Meeting those requirements calls for enabling technologies that lead to innovative and sustainable manufacturing [1].

A joint technique is one or a combination of the available mechanical, chemical, thermal processes to create a bond between materials with a number of combinations and geometries. Welding processes of metal alloys use a thermal energy source that can either melt materials of similar compositions and melting points or produce coalescence at temperatures essentially below the melting point of the base materials being joined. Such well-known welding processes include thermal fusion joining processes and solid-state joining processes; the latter are gaining renewed interest.

Among the thermal fusion joining processes, the most common process is electric arc welding. Several methods use the electric arc approach for fusion welding of steel [2], aluminum [3], titanium [4] and magnesium alloys [5]. The selection of filler material is critical for the quality of the dissimilar metal welds [6].

Laser beam and electron beam welding are high-energy beam welding methods that can operate in either melt-in/conduction or keyhole mode. In the latter mode, the laser beam is highly effective at welding metals. Similar and dissimilar weld can be produced for appliance, automotive, and aerospace applications [7-9].

Brazing and soldering involve a filler material, heated to its melting temperature, and applied between the mating parts, which do not melt. Recently, laser autogenous brazing has enabled the selective use of the unique properties exhibited by biocompatible materials such as stainless steel and shape memory materials, such as NiTi, to tailor the properties of implantable medical devices [10]. Important mid-temperature thermoelectric materials such as $\mathrm{Pb}$ Te-based alloys can be successfully brazed to form a thermoelectric module [11].

Resistance spot welding, which dominates the steel body-in-white production, involves a strong current through the metal combination that heats up and finally melts the metals at localized points. A force is applied before, during and after the application of the current to confine the contact area at the weld interfaces and, in some applications, to forge the workpieces. Similar [12] and dissimilar [13] weld can be easily produced.

Within the solid-state joining process, friction stir welding has gained a prominent position. Invented in 1991, it uses a non-consumable tool to join two facing workpieces without melting the workpiece material. Heat is generated by friction between the rotating tool and the workpiece material. This welding method has great capability at welding lightweight [14] and dissimilar weld [15]. Otherwise, friction welding is a process where the two pieces are moved relatively by means of an upsetting force. The relative motion heats the two pieces to a plastic-state. Two friction welding processes are available: linear friction welding and rotary friction welding [16].

Ultrasonic welding uses high frequency ultrasonic vibration for joining materials, such as in lithium-ion battery manufacturing, carbon fiber reinforced polymer-aluminum weld and dissimilar joining of aluminum to copper [17]. 
In solid-state welding by plastic deformation, a metallurgical bond can be obtained by large plastic deformation. The use of plastic deformation for joining parts potentially offers improved accuracy, reliability and environmental safety as well as creating opportunities to design new products through joining dissimilar materials [18].

Finally, hybrid welding is a joining process that simultaneously combines two welding processes in the same weld pool. The hybrid process has the individual advantages of both welding processes. The laser can be coupled with the arc for the well-established laser-arc hybrid welding of similar and dissimilar metals [19-21]. Moreover, the laser beam can assist the friction stir welding process via preand post-welding heating [22,23].

\section{The Present Issue}

This Special Issue is dedicated to welding technologies: modeling and simulation; evolution of microstructure and properties in welds; prediction of residual stress, distortion, fatigue, and corrosion; weld quality and qualification; and destructive and non-destructive control. Various important aspects have been addressed in the 17 papers that were published.

Park et al. have evaluated the fracture toughness of several different weldments for $7 \%$ nickel alloy steels. The weldment of 7\% nickel alloy steel was fabricated by tungsten inert gas (TIG), flux cored arc welding (FCAW), and gas metal arc welding (GMAW) [24].

Cárcel-Carrasco et al. have examined the weldability of ductile cast iron when the root weld is applied with a tungsten inert gas (TIG) welding process employing an Inconel 625 source rod, and when the filler welds are applied with electrodes coated with $97.6 \% \mathrm{Ni}$ [25].

Fall et al. have investigated the tool wear and its wear rate during friction stir welding (FSW) of Ti-6Al-4V alloy. A conical tungsten carbide tool was used to produce butt-type friction stir welded joints in two-millimeter thick Ti-6Al-4V sheets [26].

Russo Spena et al. have studied the spot weldability of a new advanced Quenching and Partitioning (Q \& P) steel and a Transformation Induced Plasticity (TRIP) steel for automotive applications by evaluating the effects of the main welding parameters on the mechanical performance of dissimilar spot welds [27].

Song et al. have characterized the interfacial microstructures of $316 \mathrm{~L}$ stainless steel $(\mathrm{Fe}-18 \mathrm{Cr}-11 \mathrm{Ni})$ and a Kovar (Fe-29Ni-17Co or 4J29) diffusion, bonded via vacuum hot-pressing in a temperature range of $850-950{ }^{\circ} \mathrm{C}$ with an interval at $50^{\circ} \mathrm{C}$ for $120 \mathrm{~min}$ and at $900{ }^{\circ} \mathrm{C}$ for 180 and $240 \mathrm{~min}$, under a pressure of 34.66 MPa [28].

Gangwar et al. have presented the microstructural and mechanical properties of the joints for ATI-425 and TIMET-54M friction stir welding. The evolution of microstructure and concomitant mechanical properties were characterized by optical microscopy, microhardness, and tensile properties [29].

Sun et al. have presented a metallurgical and mechanical characterization of $2 \mathrm{~mm}$ thick 6061-T6 Al alloy plates [30].

Yuce et al. have achieved the process parameters' optimization procedure of fiber laser welding of dissimilar high strength low alloy (HSLA) and martensitic steel (MART) using a Taguchi approach. The influence of laser power, welding speed and focal position on the mechanical and microstructural properties of the joints was determined [31].

Yi et al. have demonstrated the effectiveness of using tungsten inert gas (TIG) dressing to remove weld pores, and changes in the mechanical properties due to the TIG dressing of Ti-3Al-2.5V weldments [32].

Ahmad et al. have performed multi-pass dissimilar material welding between Alloy 617 and 12Cr steel, performed under optimum welding conditions. The mechanical properties indicated that the yield strength and tensile strength of the dissimilar metal welded joint were higher than those of the Alloy 617 base metal [33]. 
Chai et al. have realized Hastelloy C-276 thin sheet- $0.5 \mathrm{~mm}$ in thickness-weld, with filler wire using a pulsed laser. The results indicated that the weld pool geometry and microstructure were significantly affected by the duty ratio, which was determined by the pulse duration and repetition rate under a certain heat input [34].

Chang et al. have studied the effects of laser power on the remanence (Br), experimentally investigated in laser spot welding of a $\mathrm{NdFeB}$ magnet $(\mathrm{N} 48 \mathrm{H})$. Results show that the Br decreased with the increase of laser power. For the same welding parameters, the Br of magnets, that were magnetized before welding, were much lower than that of magnets that were magnetized after welding [35].

Oh et al., assuming non-uniform part-to-part gaps, have examined the effects of welding direction on the quality of the joint of galvanized steel sheets SGARC440 (lower part) and SGAFC590DP (upper part), examined using 2-kW fiber and 6.6-kW disk laser welding systems [36].

Kang et al. have studied $\mathrm{CaO}$-added $\mathrm{Mg}$ alloy weld. Mechanical and metallurgical aspects of the weldments were analyzed after welding, and welding behaviors such as fume generation and droplet transfer were observed during welding [37].

Chen et al. have examined the effects of reflow time on the interfacial microstructure and shear strength of the SAC/FeNi-Cu connections. It was found that the amount of Cu6Sn5 within the solder did not have a noticeable increase after a long time period of reflowing [38].

Ji et al. have studied dissimilar joints with Ti-6Al-4V and Ti-5Al-2Sn-2Zr-4Mo-4Cr alloys via optical microscopy and scanning electron microscopy (SEM). The welds were obtained by linear friction welding [39].

Dewa et al. have comparatively investigated the low cycle fatigue behavior of Alloy 617 (INCONEL 617) weldments by the gas tungsten arc welding process at room temperature and $800{ }^{\circ} \mathrm{C}$ in the air to support the qualification, in high temperature applications, of the Next Generation-IV Nuclear Plant [40].

All the contributions have outlined problems and given solutions in order to achieve further progress in welding. The overall information provides a good foundation for future developments in welding processes and materials in manufacturing industries.

Finally, I would like to take this opportunity to thank all the authors for their contributions to this Special Issue, and the reviewers for their expert review comments. I would also like to thank the managing editor Natalie Sun and the entire staff of the Metals Editorial Office for their advice and support during the preparation of this Special Issue.

\section{References}

1. Martinsen, K.; Hu, S.J.; Carlson, B.E. Joining of dissimilar materials. CIRP Ann. Manuf. Technol. 2015, 64, 679-699. [CrossRef]

2. Vashishtha, H.; Taiwade, R.V.; Sharma, S.; Patil, A.P. Effect of welding processes on microstructural and mechanical properties of dissimilar weldments between conventional austenitic and high nitrogen austenitic stainless steels. J. Manuf. Process. 2017, 25, 49-59. [CrossRef]

3. Bonazzi, E.; Colombini, E.; Panari, D.; Vergnano, A.; Leali, F.; Veronesi, P. Numerical Simulation and Experimental Validation of MIG Welding of T-Joints of Thin Aluminum Plates for Top Class Vehicles. Metall. Mater. Trans. A Phys. Metall. Mater. Sci. 2017, 48, 379-388. [CrossRef]

4. Yang, M.; Zheng, H.; Qi, B.; Yang, Z. Effect of arc behavior on Ti-6Al-4V welds during high frequency pulsed arc welding. J. Mater. Process. Technol. 2017, 243, 9-15. [CrossRef]

5. Guo, J.; Zhou, Y.; Liu, C.; Wu, Q.; Chen, X.; Lu, J. Wire arc additive manufacturing of AZ31 magnesium alloy: Grain refinement by adjusting pulse frequency. Materials 2016, 9. [CrossRef]

6. Liu, K.; Li, Y.; Wang, J. Improving the Interfacial Microstructure Evolution of Ti/Stainless Steel GTA Welding Joint by Employing Cu Filler Metal. Mater. Manuf. Process. 2016, 31, 2165-2173. [CrossRef]

7. Casalino, G.; Guglielmi, P.; Lorusso, V.D.; Mortello, M.; Peyre, P.; Sorgente, D. Laser offset welding of AZ31B magnesium alloy to 316 stainless steel. J. Mater. Process. Technol. 2017, 242, 49-59. [CrossRef] 
8. Yang, G.; Ma, J.; Wang, H.-P.; Carlson, B.; Kovacevic, R. Studying the effect of lubricant on laser joining of AA 6111 panels with the addition of AA 4047 filler wire. Mater. Des. 2017, 116, 176-187. [CrossRef]

9. Casalino, G.; Mortello, M.; Peyre, P. Yb-YAG laser offset welding of AA5754 and T40 butt joint. J. Mater. Process. Technol. 2015, 223, 139-149. [CrossRef]

10. Satoh, G.; Brandal, G.; Naveed, S.; Yao, Y.L. Laser Autogenous Brazing of Biocompatible, Dissimilar Metals in Tubular Geometries. J. Manuf. Sci. Eng. Trans. ASME 2017, 139, 041016. [CrossRef]

11. Chen, S.-W.; Wang, J.-C.; Chen, L.-C. Interfacial reactions at the joints of PbTe thermoelectric modules using Ag-Ge braze. Intermetallics 2017, 83, 55-63. [CrossRef]

12. Yuan, X.; Li, C.; Chen, J.; Liang, X.; Pan, X. Resistance spot welding of dissimilar DP600 and DC54D steels. J. Mater. Process. Technol. 2017, 239, 31-41. [CrossRef]

13. Ling, Z.; Li, Y.; Luo, Z.; Feng, Y.; Wang, Z. Resistance Element Welding of 6061 Aluminum Alloy to Uncoated 22MnMoB Boron Steel. Mater. Manuf. Process. 2016, 31, 2174-2180. [CrossRef]

14. Ahmed, M.M.Z.; Ataya, S.; El-Sayed Seleman, M.M.; Ammar, H.R.; Ahmed, E. Friction stir welding of similar and dissimilar AA7075 and AA5083. J. Mater. Process. Technol. 2017, 242, 77-91. [CrossRef]

15. Liu, X.; Chen, G.; Ni, J.; Feng, Z. Computational Fluid Dynamics Modeling on Steady-State Friction Stir Welding of Aluminum Alloy 6061 to TRIP Steel. J. Manuf. Sci. Eng. Trans. ASME 2017, 139, 5. [CrossRef]

16. Vairis, A.; Papazafeiropoulos, G.; Tsainis, A.-M. A comparison between friction stir welding, linear friction welding and rotary friction welding. Adv. Manuf. 2016, 4, 296-304. [CrossRef]

17. Ni, Z.L.; Ye, F.X. Dissimilar Joining of Aluminum to Copper Using Ultrasonic Welding. Mater. Manuf. Process. 2016, 31, 2091-2100. [CrossRef]

18. Mori, K.-I.; Bay, N.; Fratini, L.; Micari, F.; Tekkaya, A.E. Joining by plastic deformation. CIRP Ann. Manuf. Technol. 2013, 62, 673-694. [CrossRef]

19. Leo, P.; Renna, G.; Casalino, G.; Olabi, A.G. Effect of power distribution on the weld quality during hybrid laser welding of an Al-Mg alloy. Opt. Laser Technol. 2015, 73, 118-126. [CrossRef]

20. Casalino, G.; Campanelli, S.L.; Ludovico, A.D. Laser-arc hybrid welding of wrought to selective laser molten stainless steel. Int. J. Adv. Manuf. Technol. 2013, 68, 209-216. [CrossRef]

21. Subashini, L.; Phani Prabhakar, K.V.; Gundakaram, R.C.; Ghosh, S.; Padmanabham, G. Single Pass Laser-Arc Hybrid Welding of Maraging Steel Thick Sections. Mater. Manuf. Process. 2016, 31, 2186-2198. [CrossRef]

22. Baker, B.; McNelley, T.; Matthews, M.; Rotter, M.; Rubenchik, A.; Wu, S. Use of High-Power Diode Laser Arrays for Pre-and Post-Weld Heating during Friction Stir Welding of Steels. In Proceedings of the TMS Annual Meeting, Orlando, FL, USA, 15-19 March 2015; Volume 2015, pp. 21-36.

23. Campanelli, S.L.; Casalino, G.; Casavola, C.; Moramarco, V. Analysis and comparison of friction stir welding and laser assisted friction stir welding of aluminum alloy. Materials 2013, 6, 5923-5941. [CrossRef]

24. Park, J.Y.; Lee, J.M.; Kim, M.H. An Investigation of the Mechanical Properties of a Weldment of $7 \%$ Nickel Alloy Steels. Metals 2016, 6, 285. [CrossRef]

25. Cárcel-Carrasco, F.; Pérez-Puig, M.; Pascual-Guillamón, M.; Pascual-Martínez, R. An Analysis of the Weldability of Ductile Cast Iron Using Inconel 625 for the Root Weld and Electrodes Coated in 97.6\% Nickel for the Filler Welds. Metals 2016, 6. [CrossRef]

26. Fall, A.; Fesharaki, M.H.; Khodabandeh, A.R.; Jahazi, M. Tool Wear Characteristics and Effect on Microstructure in Ti-6Al-4V Friction Stir Welded Joints. Metals 2016, 6. [CrossRef]

27. Spena, P.R.; de Maddis, M.; D'Antonio, G.; Lombardi, F. Weldability and Monitoring of Resistance Spot Welding of Q\&P and TRIP Steels. Metals 2016, 6. [CrossRef]

28. Song, T.; Jiang, X.; Shao, Z.; Mo, D.; Zhu, D.; Zhu, M. The Interfacial Microstructure and Mechanical Properties of Diffusion-Bonded Joints of 316L Stainless Steel and the 4J29 Kovar Alloy Using Nickel as an Interlayer. Metals 2016, 6. [CrossRef]

29. Gangwar, K.; Ramulu, M.; Cantrell, A.; Sanders, D.G. Microstructure and Mechanical Properties of Friction Stir Welded Dissimilar Titanium Alloys: TIMET-54M and ATI-425. Metals 2016, 6. [CrossRef]

30. Sun, Y.; Tsuji, N.; Fujii, H. Microstructure and Mechanical Properties of Dissimilar Friction Stir Welding between Ultrafine Grained 1050 and 6061-T6 Aluminum Alloys. Metals 2016, 6. [CrossRef]

31. Yuce, C.; Tutar, M.; Karpat, F.; Yavuz, N. The Optimization of Process Parameters and Microstructural Characterization of Fiber Laser Welded Dissimilar HSLA and MART Steel Joints. Metals 2016, 6. [CrossRef]

32. Yi, H.; Lee, Y.; Lee, K. TIG Dressing Effects on Weld Pores and Pore Cracking of Titanium Weldments. Metals 2016, 6. [CrossRef] 
33. Ahmad, H.W.; Hwang, J.H.; Lee, J.H.; Bae, D.H. An Assessment of the Mechanical Properties and Microstructural Analysis of Dissimilar Material Welded Joint between Alloy 617 and 12Cr Steel. Metals 2016, 6. [CrossRef]

34. Chai, D.; Wu, D.; Ma, G.; Zhou, S.; Jin, Z.; Wu, D. The Effects of Pulse Parameters on Weld Geometry and Microstructure of a Pulsed Laser Welding Ni-Base Alloy Thin Sheet with Filler Wire. Metals 2016, 6. [CrossRef]

35. Chang, B.; Du, D.; Yi, C.; Xing, B.; Li, Y. Influences of Laser Spot Welding on Magnetic Property of a Sintered NdFeB Magnet. Metals 2016, 6. [CrossRef]

36. Oh, R.; Kim, D.Y.; Ceglarek, D. The Effects of Laser Welding Direction on Joint Quality for Non-Uniform Part-to-Part Gaps. Metals 2016, 6. [CrossRef]

37. Kang, M.; Ahn, Y.; Kim, C. Gas Metal Arc Welding Using Novel CaO-Added Mg Alloy Filler Wire. Metals 2016, 6. [CrossRef]

38. Chen, Y.; Wu, X.; Wang, X.; Huang, H. Effects of Reflow Time on the Interfacial Microstructure and Shear Behavior of the SAC/FeNi-Cu Joint. Metals 2016, 6. [CrossRef]

39. Ji, Y.; Wu, S.; Zhao, D. Microstructure and Mechanical Properties of Friction Welding Joints with Dissimilar Titanium Alloys. Metals 2016, 6. [CrossRef]

40. Dewa, R.T.; Kim, S.J.; Kim, W.G.; Kim, E.S. Low Cycle Fatigue Behaviors of Alloy 617 (INCONEL 617) Weldments for High Temperature Applications. Metals 2016, 6. [CrossRef]

(C) 2017 by the author; licensee MDPI, Basel, Switzerland. This article is an open access article distributed under the terms and conditions of the Creative Commons Attribution (CC BY) license (http:/ / creativecommons.org/licenses/by/4.0/). 